\title{
Geoscięnces
}

\section{A structural model of the Fábrica Nova region, Santa Rita syncline, Quadrilátero Ferrífero: flanking folds as a folding mechanism}

http://dx.doi.org/10.1590/0370-44672015680058

\author{
Daniel Quinaud Rossi \\ Mestre do Programa de Pós-Graduação em \\ Evolução Crustal e Recurso Naturais - DEGEO/ \\ Escola de Minas - UFOP \\ Geólogo da Gerência de Planejamento de Curto \\ Prazo da Vale S/A \\ Itabira - Minas Gerais - Brazil \\ danielgrossi@hotmail.com

\section{Issamu Endo} \\ Professor Associado do Departamento de \\ Geologia da Escola de Minas da Universidade \\ Federal de Ouro Preto \\ Ouro Preto - Minas Gerais - Brazil \\ issamu.endo@gmail.com
}

\section{Modelo estrutural da região de Fábrica Nova, Sinclinal Santa Rita, Quadrilátero Ferrífero: mecanismo de dobramento por flanking folds}

\begin{abstract}
This study focuses on the eastern flank of the Santa Rita syncline (Dorr 1969), with specific emphasis on the region known as Fábrica Nova. Important iron ore deposits are located on the flanks of this structure, such as Timbopeba, Alegria, São Luiz, Tamanduá, Almas and Fábrica Nova. The Santa Rita syncline is a fold with $\mathrm{N}-\mathrm{S}$ axial direction and of subregional scale, with roots in the adjacent basement of the Santa Bárbara Complex and sectioned by the Água Quente thrust fault. The hypothesis of this study is that the structural framework of the region resulted from the superposition of at least three deformation phases on the Ouro Preto nappe. The Fábrica Nova mine, located in the central portion of the study area, is embedded in a synformal structure with a 100/20 trending axis named Fábrica Nova synform. The proposed model to explain the particular structural geometry of this region is based on the flanking folding mechanism (Passchier 2001). This mechanism may have been developed by E-W crustal shortening during the $\mathrm{F}_{4}$ tectonic deformation phase.
\end{abstract}

Keywords: Geologia Estrutural, Quadrilátero Ferrífero, Sinclinal Santa Rita, Mina de Fábrica Nova.

\section{Resumo}

O presente trabalho se concentra na aba leste do sinclinal Santa Rita, (Dorr 1969), a partir da região conhecida como Fábrica Nova. Importantes depósitos de minérios de ferro estão localizados nos flancos dessa estrutura, como os de Timbopeba, Alegria, São Luiz, Tamanduá, Almas e Fábrica Nova. Esse sinclinal é uma dobra de escala sub-regional de direção axial N-S com raízes no embasamento adjacente do Complexo Santa Bárbara e seccionada pela falha de Água Quente. A investigação propõe a hipótese de que o arcabouço estrutural da região é resultante da superposição de pelo menos três fases de deformação sobre a nappe Ouro Preto. A mina de Fábrica Nova, localizada na porção central da área estudada, está inserida em uma estrutura sinformal de eixo 100/20, o sinforme de Fábrica Nova. Para a geometria particular dessa região, é proposto um modelo com base no mecanismo de dobramento por Flanking Folds (Passchier 2001). Esse mecanismo se daria através de um encurtamento crustal de direção $E$ - $W$ da fase de deformação $F_{4}$.

Palavra-chave: Geologia Estrutural, Quadrilátero Ferrifero, Santa Rita Syncline, Fábrica Nova de Minas, Fábrica Nova Syncline. 


\section{Introduction}

The area of this study is located along the eastern edge of the Quadrilátero Ferrífero (QFe) (Dorr 1969) in the central portion of Minas Gerais state between the districts of Santa Rita Durão and Bento Rodrigues in a region known as Fábrica Nova (Fig. 1).

In general, the QFe is comprised of three major sets of rock units: the metamorphic complexes of Archean age, the metavolcanic-metassedimentary rocktype sequence of the greenstone-belt of
Archean age, corresponding to the Rio das Velhas Supergroup, and the Paleoproterozoic supracrustal rocks of the Minas Supergroup and Itacolomi Group (e.g. Dorr et al. 1957, Dorr 1969, Cordani et al. 1980, Schorscher et al. 1982, Romano 1989, Noce 1995, Machado et al. 1996, Alkmim \& Marshak 1998).

The regional structure of the QFe is the result of the superposition of two main tectonic events (Chemale Jr. et al. 1991), namely the Transama-

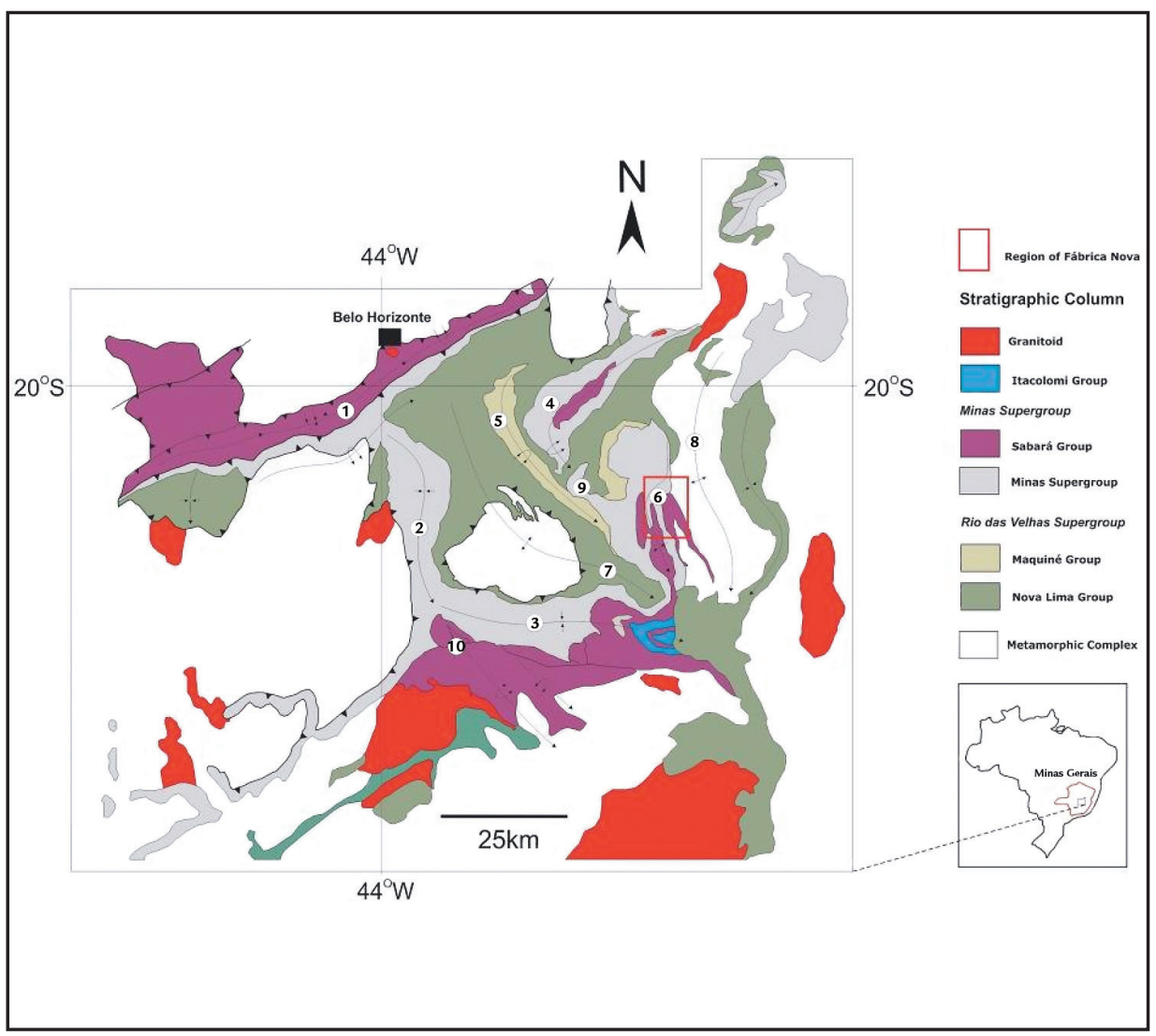

The eastern edge of the QFe represents the border between the São Francisco craton and the Araçuaí Belt (e.g., Alkmim et al. 2006), and its structure is conditioned by the Fundão-Cambotas (Endo \& Fonseca 1992) and Água Quente thrust fault systems (Maxwell 1972, Ferreira $F^{\circ}$. 1999). The Santa Rita syncline (Fig. 1) is located within this system and, according to Dorr (1969) and Maxwell (1972), it is characterized as an asymmetric synform with a N-NE and N-S trending axis; it is open in the southern section and narrow in the northern section, with a subhorizontal plunge. The flanks are subparallels, and the overturned flank is sectioned by the Água Quente fault, which is of submeridian trace. The stratigraphic units on the overturned flank are thin- ner than its normal counterpart flank located to the west. Schists, phyllites, and ferruginous quartzites belonging to the Piracicaba and Sabará groups are present in the core.

Dorr (1969) argued that mesoscopic fold axes show subhorizontal plunge with axial trace parallel to the bedding direction in contrast. In turn Endo (1997) described fold axes with moderate plunging around $45^{\circ}$ toward the E-SE. At the hinge of the Santa Rita syncline, the bedding shows steep dipping to the E bisected by penetrative regional schistosity, with an intersection lineation parallel to the corresponding mineral and stretching lineation plunging toward the E-SE (e.g. Ferreira $\mathrm{F}^{\mathrm{o}}$. 1999, Ferreira F ${ }^{\circ}$. \& Fonseca 2001). This relationship between the linear fabrics zonian $(2.1-2.0 \mathrm{Ga})$ and Brasiliano $(0.8-0.6 \mathrm{Ga})$ orogenies. The first event produced the regional recumbent synclines and anticlines on the supracrustal rocks and the uplifting of gneissic-granite rocks arranged in structures like a nappe (Almeida 2004, Endo et al. 2005), and the second caused the inversion, amplification, translation and crustal rotation of the synclines and anticlines around the dome structures.
Figure 1

A summary geological map of the QFe and the location of the study area. Axial trace of Mangabeiras syncline (1), Moeda syncline (2), Dom Bosco syncline (3), Gandarela syncline (4), Vargem do Lima syncline (5), Santa Rita syncline (6), Mariana anticline (7), Furquim anticline (8), Ouro Fino syncline (9), Santo Antônio anticline (10) (model by Dorr 1969, Romano 1989, Endo 1997, Almeida 2004, Endo et al. 2004, Endo et al. 2005).

predominates in the QFe region (Chemale Jr. et al. 1991, Alves 1991, Alkmim \& Marshak 1998, Franco 2003, Almeida 2004, Endo 1997, Endo et al. 2005).

According to the models of Dorr (1969) and Maxwell (1972), the correct position of the Santa Rita syncline hinge has not been determined so far. Contemporary structures such as the Gandarela and Ouro Fino synclines, have hinges with E-SE plunges parallel to the intersection and mineral stretching lineations at approximately 100/45 (Franco 2003, Endo et al. 2004). The bedding trace contour of the Minas Supergroup units of the Fábrica Nova region seems to indicate a "Z" type folding geometry (Fig. 3). If this hypothesis is correct, the syncline closure should occur in its southern section. 
Figure 2

View of Fábrica Nova mine with the location of Santa Rita Durão district and Caraça region (Vale file).



\section{Materials and Methods}

This study was conducted in two phases. The first phase involved regional lithostructural mapping on a 1:5.000 scale, and the second stage included detailed mapping of the northern and southern pits of the Fábrica Nova mine (Fig. 2) on a 1:2.000 scale. The lithostratigraphic and structural data collected from this semi-detailed geological map enabled the proposal of a geological model for the Santa Rita syncline, especially with regard to the geometry of the Fábrica Nova region. The structural data collected during the mapping were launched in stereograms using GEOrient (v. 9.0) software.
Based on structural criteria proposed by Harland (1956), Hansen (1971), Robertson (1994), Hsue (1995), and Xypolias (2010), the study area was divided into two structural domains according to their structural styles, geometry, and fabric properties: eastern and western (Fig. 3).
Figure 3

The structural domains adopted in the regional mapping.



REM: R. Esc. Minas, Ouro Preto, 68(2), 153-162, apr. jun. | 2015 
The structural asymmetry and the vorticity were characterized according to the down-plunging view of the fold axis or the intersection lineation (Passchier \& Williams 1996, Xypolias 2009 and 2010). The characteristics of each domain are as follows:

The eastern domain encompasses the units of the Sabará Group (e.g. Gair 1958, Barbosa 1968, Renger et al. 1994, Almeida 2004, Almeida et al. 2005)

\section{Results}

The structural analysis was based on the structural framework from dif-

\section{Mesoscopic Structures Bedding}

The bedding was defined by the variation in the particle size of the quartz grains in the quartzites of the Moeda and Cercadinho formations and the Sabará Group as well as the alternating laminae rich in quartz and the hematitemagnetite-goethite in the itabirite of the Cauê Formation.

\section{Structures of the First Deformation Phase $\left(F_{1}\right)$}

The structures that reflect this phase are represented by tight and asymmetric mesofolds, most likely associated with an S1 foliation oblique to the bedding. The rare asymmetric folds, relicts of this phase, have a " $Z$ ” pattern. In one of the few outcrops where the structures of this deformation phase were found, and the Santa Bárbara Complex (Dorr 1969, Herz 1970). The structural data obtained in this field suggests that the rocks of these units are folded as to form an antiform $\mathrm{F}_{2}$ with axis plunging toward to ESE.

The Minas Supergroup (Dorr 1969) units comprise the western domain on an overturned stratigraphic position. The outline of these units forms a structure that resembles a boomerang geometry and a " $Z$ " folding pattern associated with a clockwise vorticity. The Bento Rodrigues fault determines the boundary between these two structural domains.

Due to structural characteristics the western domain can be divided into two subdomains: IIa and IIb, which correspond to the northern and southern pits, respectively, of the Fábrica Nova mine (Fig. 3). ferent observation scales (e.g. Williams 1985, Xypolias 2010). To better describe the structures, they were arranged into mesoscopic and macroscopic categories.
The bedding planes of quartzites of the Sabará Group in the eastern domain shows a NW-SE direction and dipping toward to NE at 056/54 (Fig. 6a). The bedding in the western domain was preserved in all of the units of the Minas Supergroup with a preferential NW-SE direction at the south and an E-W direction at the north of

the domain, with a maximum of approximately 172/48 (Fig. 6b). The dispersion of the bedding orientation suggests the acting of the F4 folding phase with an axial trend at approximately $117 / 33$. This fold, named Fábrica Nova synform, is characterized as an open, subcylindrical and asymmetric fold with plunge.

the bedding and S1 foliation relationship observed presents a clockwise vorticity in a " $Z$ " pattern, which are preserved in the sericitic schist. In the silvery phyllite layer, the bedding and $S_{2}$ foliation relationship exhibits a counterclockwise vorticity in an "S" pattern. The interference relationship is characterized by the

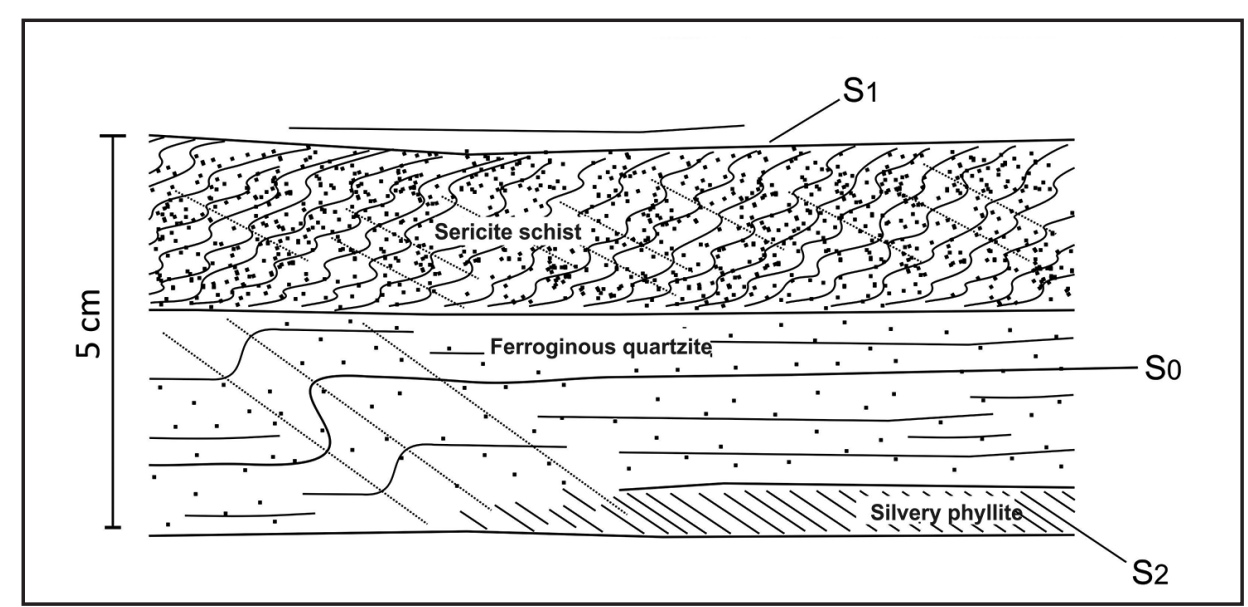

\section{Structures of the Second Deformation Phase $\left(F_{2}\right)$}

The $\mathrm{S}_{2}$ regional schistosity is a penetrative planar fabric characterized by the preferential orientation of minerals such as sericite (Fig. 5a), hematite, and quartz. In the eastern domain, the $S_{2}$ schistosity has an attitude of approximately 066/55 (Fig. $6 c)$. In the western domain, the arrange- ment of the mapped units clearly expresses a folded system in which the $S_{2}$ schistosity shows an attitude of approximately 082/43 (Fig. 6d). The attitude of the axis of this fold $\left(\mathrm{B}_{4}\right)$ is $104 / 40$. The F2 folds, which have been mostly mapped in the Fábrica Nova mine, are tight folds with superposition of the $S_{2}$ regional schistosity folding the $S_{1}$ foliation with the same vorticity pattern as the $\mathrm{F}_{2}$ deformation phase (Fig. 4).

However, the original characteristics of this fabric were mostly obliterated by the subsequent deformation phases in most of the studied region.

Figure 4

A schematic drawing of a sample from the Cercadinho Formation at a mesoscopic scale showing the superposition of two deformation phases represented by the S1 and S2 foliations with opposite vorticities. Plane view XZ strain axes.

an axis plunging slightly to the ESE and a major attitude of approximately 119/21 in the northern pit (subdomain IIa; Fig. 6e) and 093/17 in the southern pit (subdomain IIb; Fig. 6f). These folds are asymmetric with "S" patterns, furthermore, they have wavelengths and amplitudes on the order 
of a few meters (Fig. 5b). A box-fold pattern can be observed in subdomain IIa and is interpreted as the manifestation of the superposition of the $F_{2}$ folds over the F1 folds with opposite vorticities. The " $S$ " folds in this system are better preserved than the " $Z$ " folds, attesting to the super-

Figure 5

a) $\mathrm{S}_{2}$ schistosity characterized by the preferential orientation of the mineral sericite and its counterclockwise vorticity relation to the $\mathrm{S}_{0}$ bedding. Outcrop

FN-303, near Santa Rita Durão

b) Asymmetric folds with "S" patterns mapped in the Fabrica Nova mine.

\section{Structures of the Third Deformation Phase $\left(F_{3}\right)$}

The structural framework of phase $\mathrm{F}_{3}$ consists of open folds with an E-W axis featuring wavelengths and amplitudes of decametric dimensions that primarily outcrop in the Fábrica Nova mine.

The $\mathrm{S}_{3}$ foliation is a disjunctive cleavage of the E-W direction and the subvertical plunges that dips or to the position of the deformation phases. The intersection between the $S_{0}$ bedding planes and the $S_{2}$ schistosity is the predominant fabric in the itabirites of the Fábrica Nova mine. This structure shows moderate plunging to the ESE with average attitudes of approximately 094/22 (Fig. 6g). The

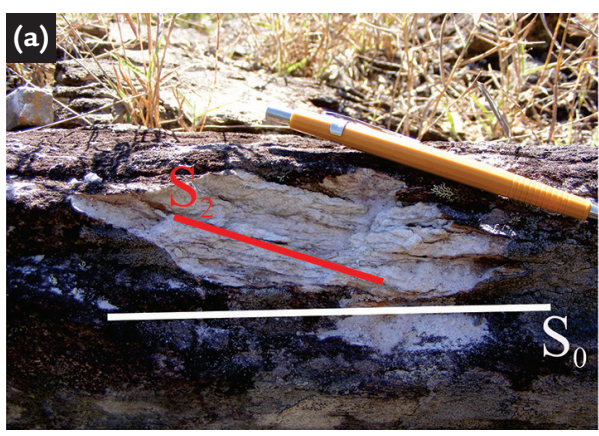

north or to the south with an attitude of approximately 018/80 (Fig. 7a) and are attributed to the third deformation phase. The open $\mathrm{F}_{3}$ mesofolds or undulations of the bedding that show an axis with moderate plunging to the ENE and kink folds with an axial plane that dips to the south are also attributed to this phase. Among the structures of mineral lineation, characterized by the preferential orientation of the mica and hematite crystals, shows an orientation parallel to the $\mathrm{L}_{2}$ intersection lineation $\left(\mathrm{S}_{0} \mathrm{xS}_{2}\right)$ and $\mathrm{B}_{2}$ fold axis, with moderate plunging to the ENE of approximately 080/25 (Fig. 6h).

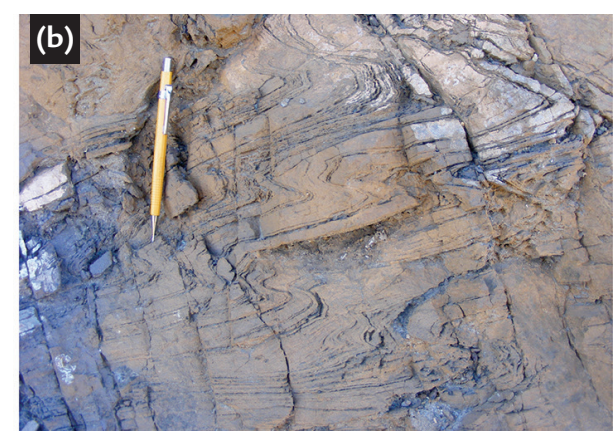

this phase, a mesofold occurring in the western portion of the Fábrica Nova northern pit stands out. This fold is an open antiform with a wavelength of approximately 200 meters and an amplitude of a few tens of a meter whose axis exhibits an attitude of 081/43 (Fig. 7b). The core of this fold is formed by silvery phyllites of the Cercadinho Formation.
Figure 6

Stereograms

of the major structures.
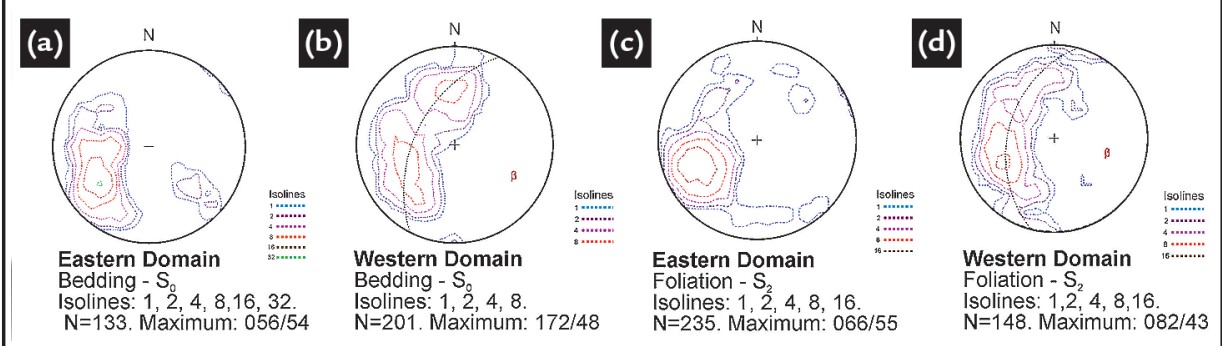

solines: $1,2,4,8,16$ $\mathrm{N}=148$. Maximum: $082 / 43$ (e)

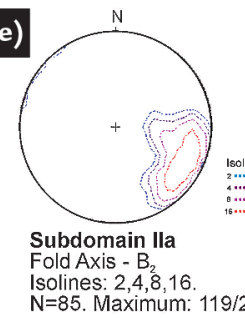

(f)



(g)

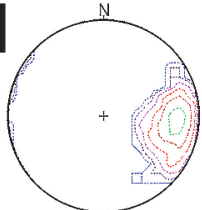

Fábrica Nova mine Lineation of SOXS2 intersection Isolines: $1,2,4,8,16,32$ $\mathrm{N}=200$. Maximum: $094 / 22$

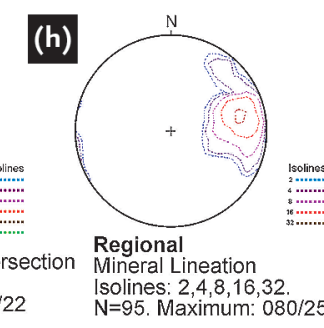

Sabará Group. The general direction of the $\mathrm{S}_{4}$ cleavage is N-S with an average attitude of 280/72 (Fig. 7c). Tight folds with steep axial plane and $\mathrm{N}-\mathrm{S}$ trending axis are also attributed to this deformation phase.

\section{Structures of the Fifth Deformation Phase $\left(F_{5}\right)$}

The records of the fracture system in the Fábrica Nova mine demonstrate the occurrence of two preferential directions, orthogonal to each other. These directions are N10-20E and N80-90 W

(Fig. 7d). 


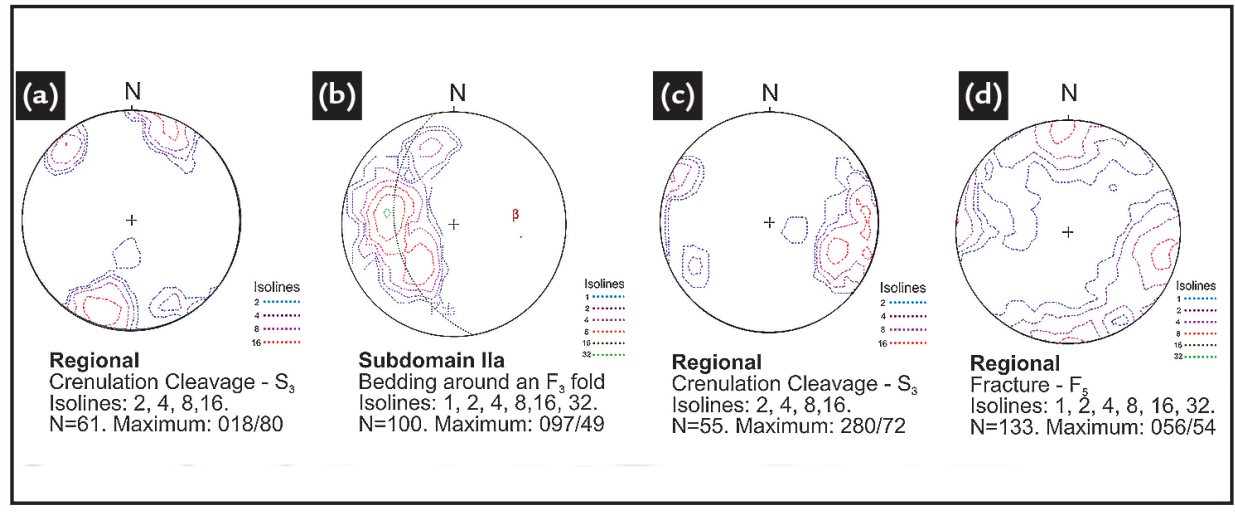

\section{Macroscopic Structures}

\section{Bento Rodrigues Fault: General Aspects and Kinematics}

The major fault of the Fábrica Nova region, hereafter called the Bento Rodrigues fault, bisects the entire mapped area, from south of Bento Rodrigues village, crossing the border east of the Fábrica Nova mine to north until Santa Rita Durão village. In the southern portion of the map, west of Bento Rodrigues, the fault trace has an NNW-SSE direction. In the central portion, near the Fábrica Nova mine, the fault trace changes its orientation

to E-W, bearing toward NNE-SSW in the northern portion of the mapped area. This structure is related to the $F_{2}$ deformation phase, which corresponds to the development of the $S_{2}$ regional schistosity and the apparent thrust of the Santa Bárbara Complex over the Minas Supergroup.

Unlike what was proposed by Dorr (1969), Maxwell (1972), Chemale Jr. et al. (1991), and Ferreira $\mathrm{F}^{\circ}$ (1999), the fault kinematics seems to be essen-
Figure 7

Stereograms of the major structures.

tially of a dextral strike-slip character with a small reverse component. The fault trajectory shows a deflection to the left relative to the bedding trace, thereby providing an extension of the layer that results in the generation of an extensional megaboudin structure. These mine-scale tectonics lead to the thinning and disappearance of the units from the Moeda and Batatal formations in the frontal portion of the Fábrica Nova mine pit.

which has an overturned character, the relationship shows clockwise vorticity with " $Z$ " asymmetric folds. The hinge of this anticline is located on the inner portion of the Fábrica Nova synform hinge and bounded to the east by the Bento Rodrigues fault.

The Alto Pai Miguel antiform is a reverse fold of a hectometric scale located in the eastern portion of the Fábrica Nova mine (Fig. 8). The core of the structure is composed of rocks from the Cercadinho Formation that outcrop in that area. Originally, these rocks were interpreted as belonging to the Batatal Formation arranged by a thrust fault. The correct modeling of this structure is of utmost importance because it will be reflected in the modeling of the mine.

\section{Discussions and conclusions}

The proposed model suggests that the Santa Rita syncline is a reclined fold of a subregional scale, with a WNWESE axial direction and roots in the adjacent basement of the Santa Bárbara Complex. The inverse flank of this syncline is bisected by the Água Quente thrust fault. This fold was generated during the Transamazonian event approximately 2,125 $\mathrm{Ma}$ ago and consists of a reclined synclinorial fold resulting from the refolding of the normal flank of the Ouro Preto nappe (e.g. Almeida 2004). The hinge zone is located in the Caraça region (Fig. 2) with axes that exhibit moderate-to-steep ESE plunging. The flanks are subparallel and the stratigraphic units are thinner in the overturned flank compared with its normal flank counterpart located to the west. Schists, phyllites, and ferruginous quartzites belong to the Piracicaba and Sabará groups are located in the core of the fold. The southern portion of the inverse flank of the Santa Rita syncline is sliced by a complex thrust fault system that Barbosa (1968) called Ouro Fino nappe. After these tectono-metamorphic events, a phase of mafic and ultramafic magmatism occurred during the pre- 


\section{Brasiliano age.}

The Fábrica Nova mine is embedded in a Fábrica Nova synform structure with axes oriented at 100/20. The direction of the bedding of the units that comprises the west flank behaves consistently and homogeneously as a homocline, which was slightly disturbed by undulations from the $\mathrm{F}_{3}$ deformation phase. The east flank bedding, in turn, was strongly disturbed by folding partially associated

Figure 8

A summary geological map of the Fábrica Nova area indicating the position of the axial traces of the Bento Rodrigues anticline (BRA), the Fábrica Nova synform (FNS) and the Alto Pai Miguel antiform (PMA).

Kinematic indicators and the structural symmetry of the $\mathrm{F}_{4}$ deformation phase are compatible with the deformation mechanism and partitioning related to the flanking fold model described and established by Passchier (2001) (Fig. 9).

Figure 9

A model of planar fabric deflection along and around the zone surrounding a cross-cutting element (CE) (Passchier 2001). In the case of Fábrica Nova, the CE is a crustal discontinuity represented by an ultramafic dike.

When considering this subregional deformation mechanism using the flanking fold as a model to understand the Fábrica Nova structural framework, the strain ratio (Rf) can be with two shortening fields due to $\mathrm{F}_{3}$ and $\mathrm{F}_{4}$ deformation phase, respectively, in the N-S and E-W direction. In addition, the brittle tectonic structures that form the sedimentary basin of the Cata Preta Formation (e.g. Castro et al. 1998, Lipski 2002) might have contributed to the rotation of the basement structures.

The relationships between the structures from the $\mathrm{F}_{4}$ deformation phase are the most complex because they do not directly respond to the regional E-W shortening field and are not laterally or regionally replicated. Cover deformation mechanisms induced by a basement-involved structures can behave actively (e.g Wilcox et al. 1973, Naylor et al. 1986, Brink et al. 1996, Erslev 1991, Narr \& Suppe 1994, Erslev \& Mayborn 1997, Tindall 2000) or passively (e.g Passchier 2001, Grasemann \& Stüwe 2001, Exner et al. 2004).

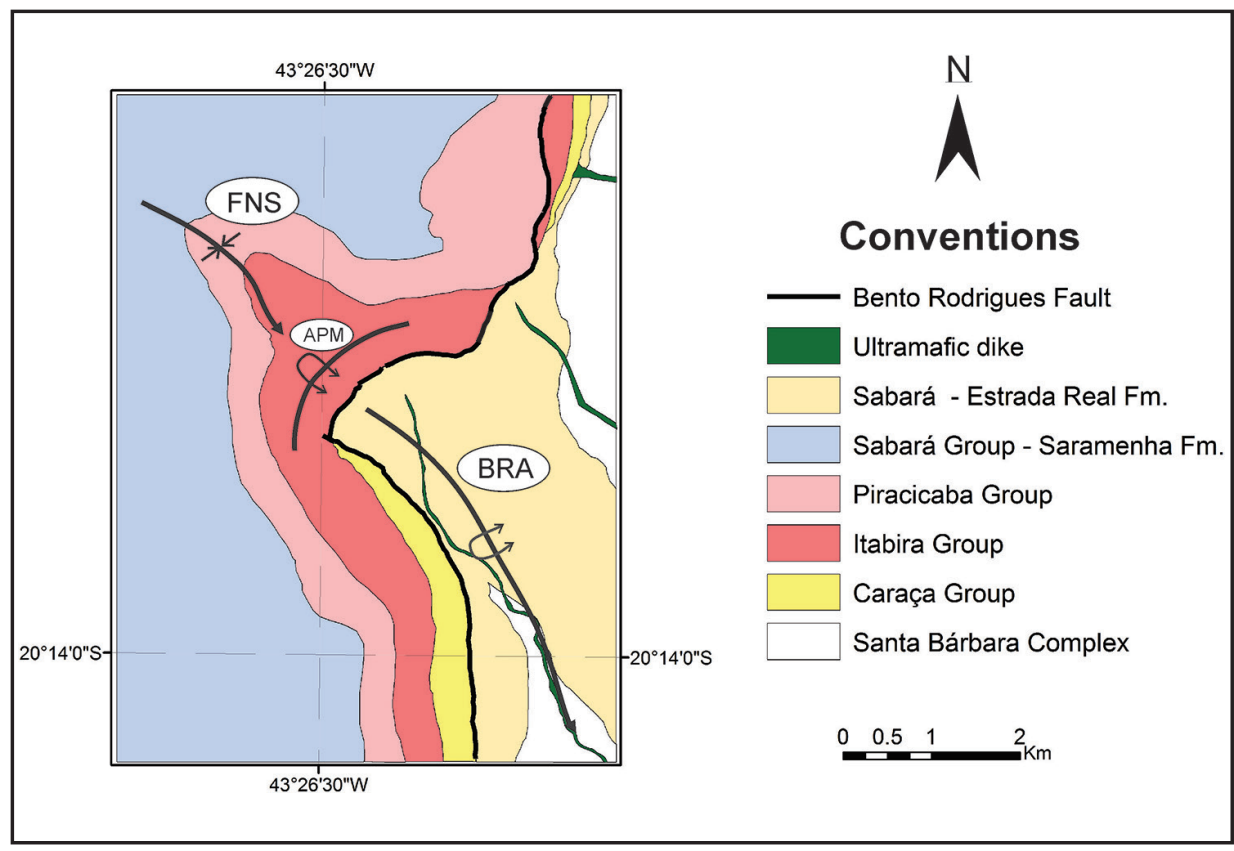

In the case of Fábrica Nova, the cross-cutting element to the regional fabric element is the crustal discontinuity that feeds the mafic rock dikes in the NW-SE direction present in this segment of the QFe (Fig. 10). Based on this mechanism, the structures of the $\mathrm{F}_{4}$ deformation phase can be understood as the manifestation of the deformation partitioning process around the major discontinuity and second-order subsidiary structures in response to the crustal shortening in the EW direction.



measured considering

i) the angular relationship of the direction of the layers in the short and long flanks and

ii) the angular relationship be- tween the crustal discontinuity, the transverse element direction, and the direction of the short flank layers (Passchier 2001). The Rf value is approximately 18.7 (Fig. 10). 


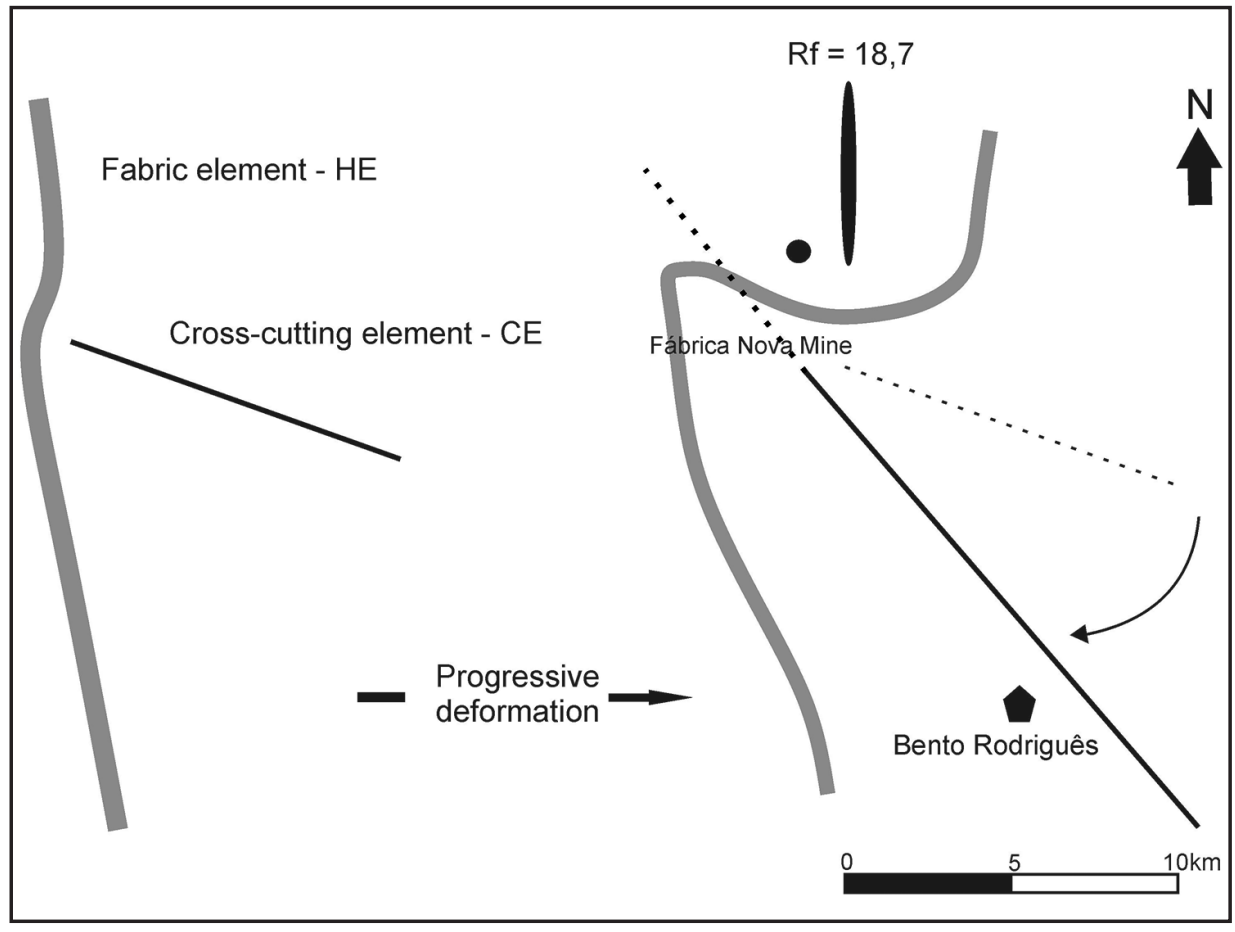

\section{Acknowledgments}

The authors thank both management departments of the VALE mining company for their collaboration: Mine Planning of Short-Term Extraction GAQAS and Mineral Exploitation of
Ferrous Management - GAEMF. The first author is grateful to the Brazilian federal agency CAPES for their scholarship and the colleagues from the Geology Department of the Federal
Figure 10

Strain ratio: Rf based on the Passchier model (2001). The fabric element "HE" represented by the top surface of the Cauê Formation and "CE" denotes the cross-cutting element represented by the direction of the crustal discontinuity filled by mafic and ultramafic rocks.

\section{References}

ALMEIDA, L. G. Evolução tectônica da porção central do sinclinal Dom Bosco, Quadrilátero Ferrífero - Minas Gerais. Minas. Ouro Preto: Departamento de Geologia, Escola de Minas, Universidade Federal de Ouro Preto. 2004. 110p. (Dissertação de Mestrado).

ALMEIDA, L. G., CASTRO, P. T., ENDO, I., FONSECA, M. A. O Grupo Sabará no Sinclinal Dom Bosco, Quadrilátero Ferrífero: uma revisão estratigráfica. Revista Brasileira de Geociências, v. 35, n. 2, p. 177-186, 2005.

ALKMIM, F. F., MARSHAK, S. Transamazonian orogeny in the Southern São Francisco Craton Region, Minas Gerais, Brazil: evidence for Paleoproterozoic collision and collapse in the Quadrilátero Ferrífero. Precambrian Research, v. 90, n. 1-2, p. 29-58, 1998.

ALKMIM, F. F; MARSHAK, S., PEDROSA-SOARES, A. C., PERES, G. G., CRUZ, S. C. P., WHITTINGTON, A. Kinematic evolution of the Araçuaí -West Congo orogen in Brazil and Africa: Nutcracker tectonics during the Neoproterozoic assembly of Gondwana. Precambrian Research, v. 149, n. 1-2, p. 43-64, 2006.

ALVES, J. A. C. Reconstrução estocástica da Mina São Luiz, Complexo Fazendão, MG, Dissertação de Mestrado. Ouro Preto: Departamento de Geologia, Escola de Minas, Universidade Federal de Ouro Preto, 1991. 120 p. (Dissertação de Mestrado).

BARBOSA, A. L. M. Contribuições recentes à geologia do Quadrilátero Ferrífero. Ouro Preto: Departamento de Geologia, Escola de Minas, Universidade Federal de Ouro Preto, 1968. (Boletim).

BRINK, U. TEN, S., KATZMAN, R., LIN, J. Three-dimensional models of deformation near strike-slip faults. Journal of Geophysical Research, v. 101, n. B7, p.16.205-16.220, 1996.

CASTRO, E. C., FERREIRA, J. E., CASTRO, P. T. A. Formação Cata Preta: uma nova unidade litoestratigráfica, definida em rochas cenozóicas, no extremo leste do Quadrilátero Ferrífero. In: CONG. BRAS. GEOL., 40, 1988. Belo Horizonte. 
Anais... Belo Horizonte: SBG, 1998. p. 81.

CHEMALE, F. Jr., ROSIÈRE, C. A., ENDO, I. Evolução tectônica do Quadrilátero Ferrífero, Minas Gerais: um modelo. Pesquisas, v. 18, n. 2, p. 104-127, 1991.

CORDANI, U. G., KAWASHITA, K., MULLER, G., QUADE, H., REIMER, V., ROESER, H. Interpretação tectônica e petrológica de dados geocronológicos do embasamento na borda sudeste do Quadrilátero Ferrífero, MG. Academia Brasileira de Ciências. v.52, n.4, p. 785-799, 1980.

DORR, J. V. N. II. Physiographic, stratigraphic and structural development of the Quadrilátero Ferrífero, Minas Gerais, Brazil . USGS/DNPM. Professional Paper 641-A., 1969. 110p.

DORR, J. V. N. II., GAIR, J. E., POMERENE, J. B., RYNEARSON, G. A. Revisão Estratigráfica Pré-Cambriana do Quadrilátero Ferrífero. Rio de Janeiro, DNPM/DFPM, 1957. 36p (Avulso. 81).

ENDO, I. Regimes tectônicos do Arqueano e Proterozóico no Interior da Placa Sanfranciscana: Quadrilátero Ferrífero e áreas adjacentes, Minas Gerais. São Paulo: Instituto de Geociências da Universidade de São Paulo. 1997. 243p. (Tese de Doutorado) .

ENDO, I., FONSECA, M. A. Sistema de cisalhamento Fundão-Cambotas no Quadrilátero Ferrífero, MG: geometria e cinemática. Revista Escola de Minas, v. 45, n. 1/2, p.15-17, 1992.

ENDO, I., SILVA, L. G., ZAVAGLIA, G., ROCHA, F. O. G., GUIMARÃES, M. L. V., ROSAS, C. F., LAGOEIRO, L. E., SANTOS, G. J. I. Arcabouço estrutural e modelo evolutivo do Sinclinal Gandarela, Quadrilátero Ferrífero, MG. In: CONGRESSO BRASILEIRO DE GEOLOGIA, 42. ARAXÁ, MG, 2004. (Resumo).

ENDO, I., OLIVEIRA, A. H., PERES, G. G., GUIMARÃES, M. L. V., LAGOEIRO, L. E., MACHADO, R., ZAVAGLIA, G., ROSAS, C. F., MELO, R. J. Nappe Curral: uma megaestrutura alóctone do Quadrilátero Ferrífero e controle da mineralização. In: SIMPÓSIO NACIONAL DE ESTUDOS TECTÔNICOS, 10; INTERNATIONAL SYMPOSIUM ON TECTONICS, 4. Curitiba, p. 279-282, 2005. Boletim de Resumos Expandidos.

ERSLEV, E. A. Trishear fault-propagation folding. Geology, v.19, p.617-620, 1991.

ERSLEV, E. A., MAYBORN, K. R. Multiple geometries and modes of fault-propagation folding in the Canadian thrust belt. Journal of Structural Geology, v. 19, n. 3-4, p. 321-335, 1997.

EXNER, U., MANCKTELOW, N. S., GRASEMANN, B. Progressive development of s-type flanking folds in simple shear. Journal of Structural Geology v. 26, p. 2191-2201, 2004.

FRANCO, A. S. P. Geometria e evolução tectônica do sinclinal Ouro Fino. Quadrilátero Ferrífero, MG. Ouro Preto: Departamento de Geologia, Escola de Minas, Universidade Federal de Ouro Preto. 102p., 2003. 102 p. (Dissertação de Mestrado)

FERREIRA, F F. A., FONSECA, M. A. Partição da deformação em regimes contracionais de antepaís: exemplo do sistema de falhas Água Quente. Revista Brasileira de Geociências, v. 31, n. 3, p.267-278, 2001.

GAIR, J.E. The Sabará Formation. In: SYMPOSIUM ON STRATIGRAPHY OF MINAS SERIES IN THE QUADRILÁTERO FERRÍFERO, MINAS GERAIS, BRAZIL. BOLETIM SBG, v.7, n.2, p.68-69, 1958.

GEORIENT v. 9.0 packages. Structural Geology - Mapping/GIS Software for Microsoft Windows. Disponível <http://sur.ly/o/holcombe.net.au/software\%2Frodh_ software_georient.htm/AA001290>. Acesso em 18.fev.2015, 12:14

GRASEMANN, B., STÜWE, K. The development of flanking folds during simple shear and their use as kinematic indicators. Journal of Structural Geology, v. 23, p. 715-724, 2001.

HANSEN, E. Strain facies: minerals, rocks and inorganic material. Berlin: Springer Verlag, 1971. 209p.

HARLAND, W. B. Tectonic facies, orientation, sequence, style and date. Geological Magazine. v. 93, p.110-120, 1956.

HERZ, N. Gneissic and igneous rocks of the Quadrilátero Ferrífero, Minas Gerais, Brazil . USGS/DNPM, 1970. 57 p. (Professional Paper 641-B).

HSUE, K. J. The geology of Switzerland : an introduction to tectonic facies. Princeton University Press, 1995. 250 p. (Monograph; ISBN 0691087873).

LIPSKI, M. Tectonismo cenozóico no Quadrilátero Ferrífero, Minas Gerais. Ouro 
Preto: Departamento de Geologia, Escola de Minas, Universidade Federal de Ouro Preto. 2002. 171 p. (Dissertação de Mestrado)

MACHADO, N., SCHRANK, A., NOCE, C.M., GAUTHIER, G. Ages of detrital zircon from Archean-Paleoproterozoic sequences: implications for greenstone belt setting and evolution of a transamazonian foreland basin in Quadrilátero Ferrífero, Southeast Brazil. Earth and Planetary Science Letters, v. 141, p. 259-276, 1996.

MAXWELL, C. H. Geology and ore deposits of the Alegria district, Brazil. Washington: USGS/DNPM, 1972. 72p. (Professional Paper 341J) 72p.

NARR, W., SUPPE, J. Kinematics of basement-involved compressive structures. American Journal of Science, v. 294, p. 802-860, 1994.

NAYLOR, M. A., MANDL, G., SIJPESTEIJN, C. H. K. Fault geometries in basement-induced wrench faulting under different initial stress states. Journal of Structural Geology, v.8, n. 7, p. 737-752, 1986.

NOCE, C. M. Geocronologia dos eventos magmáticos, sedimentares e metamórficos na região do Quadrilátero Ferrífero, Minas Gerais. São Paulo: Instituto de Geociências, Universidade de São Paulo, 1995.128 p. (Tese de Doutorado).

PASSCHIER, C. W. Flanking structures. Journal of Structural Geology, v. 23, p. 951962, 2001.

PASSCHIER, C. W., WILLIAMS, P. R. Conflicting shear sense indicators in shear zones; the problem of non-ideal sections. Journal of Structural Geology, v. 18, n. 10, p.1281-1284, 1996.

RENGER F. E., NOCE C. M., ROMANO A. W., MACHADO N. Evolução sedimentar do Supergrupo Minas: 500 Ma de registro geológico no Quadrilátero Ferrífero, Minas Gerais, Brasil. Geonomos, v. 2, n. 1, p. 1-11, 1994.

ROBERTSON, A. H. F. Role of the tectonic facies concept in orogenic analysis and its application to Tethys in the Eastern Mediterranean region. Earth-Science Reviews, v. 37, n. 3, p.139-213, 1994.

ROMANO, A. W. Evolution tectonique de la région $\mathrm{NW} d u$ Quadrilatère Ferrifère - Minas Gerais, Brésil. Nancy, France : Université de Nancy I, 1989. 259p. (Thèse Docteur).

SCHORSCHER, H. D., SANTANA, F. C., POLÔNIA, J. C., MOREIRA, J. M. P. Quadrilátero Ferrífero - Minas Gerais State: Rio das Velhas Greenstone Belt and Proterozoic rocks. In: INTERNATIONAL SYMPOSIUM ON ARCHEAN AND EARLY PROTEROZOIC EVOLUTION AND METALLOGENESIS, Salvador, 1982. Anais .... Salvador, SBG. p.43, 1982.

TINDALL, S. E. The Cockscomb Segment of the East Kaibab Monocline: taking the structural plunge. Geology of Utah's Parks and Monuments. Utah Geological Association Publication 28, 2000.

XYPOLIAS, P. Vorticity analysis in shear zones: a review of methods and applications. Journal of Structural Geology, v. 32. p.2072-2092, 2010.

XYPOLIAS, P. Some new aspects of kinematic vorticity analysis in naturally deformed quartzites. Journal of Structural Geology, v. 31. p. 3-10, 2009.

WILCOX, R. E., HARDING, T. P., SEELY, D. R. Basic Wrench Tectonics. The American Association of Petroleum Geologists of Bulletin, v. 57, n. 1, p.74-96, 1973.

WILLIANS, P. F. Multiply deformed terrains problems of correlation. Journal of Structural Geology, v. 7, n. 3/4, p.269-280, 1985.

Received: 03 April 2014 - Accepted: 23 March 2015 